\title{
Activity of Euterpe edulis Martius, Mikania glomerata Spreng, and Mikania laevigata Schultz Bip. Extracts on Gastrointestinal Nematodes Toxocara canis and Ancylostoma caninum
}

\author{
Tatiana Tonini Zamprogno ${ }^{1}$; Aline del Carmen Garcia Lopes ${ }^{1}$; Tracy Lacerda ${ }^{1}$; Emy Hiura ${ }^{1}$; \\ Leandro Abreu da Fonseca ${ }^{2}$; Thiago Senna ${ }^{1}$; Filippe Elias Freitas Soares ${ }^{3}$; Denise Coutinho \\ Endringer ${ }^{1}$; Jackson Victor Araujo ${ }^{2}$; Fabio Ribeiro Braga ${ }^{1,2,}$ \\ ${ }^{1}$ University Vila Velha, Vila Velha, Brazil \\ ${ }^{2}$ Department of Veterinary Medicine, Federal University of Vicosa, Vicosa, Brazil \\ 3 Department of Biochemistry and Molecular Biology, Federal University of Vicosa, Vicosa, Brazil \\ ${ }^{*}$ Corresponding author: Fabio Ribeiro Braga, Department of Veterinary Medicine, Federal University of Vicosa, Vicosa, Brazil. Tel: +55-3138991458, Fax: +55-3138991464, E- \\ mail: fabioribeirobraga@hotmail.com \\ Received: February 2, 2015; Revised: July 7, 2015; Accepted: July 9, 2015
}

\begin{abstract}
Background: Gastrointestinal parasitoses have high rates of morbidity and mortality. Each year about 3.5 billion people are affected by these diseases and 65,000 of them die, mostly in developing countries due to lack of basic sanitation, malnutrition, and poor access to medication. Thus, they constitute an important public health problem due to causing direct health problems related to lack of piped water, absence of sewage system, and lack of orientation.

Objectives: Two in vitro assays were performed to evaluate the larvicidal and/or ovicidal activity of ethanol extracts obtained from the plants Euterpe edulis, Mikania laevigata, and Mikania glomerata on the gastrointestinal nematodes Toxocara canis and Ancylostoma caninum. Materials and Methods: In the first assay (A), T. canis eggs were exposed to three different concentrations $(0.1 \mathrm{mg} / \mathrm{mL}, 1 \mathrm{mg} / \mathrm{mL}$, and 10 $\mathrm{mg} / \mathrm{mL}$ ) of each extract, three different concentrations of albendazole (positive control), ethanol (solvent), and a negative control (no treatment), for 15 days at $26^{\circ} \mathrm{C}$, under the shelter of light in order to evaluate the percentage of embryonated eggs in the presence of these extracts. In the second assay (B), the larvicidal activities of the species studied were evaluated in the different extract concentrations (0.1 $\mathrm{mg} / \mathrm{mL}, 1 \mathrm{mg} / \mathrm{mL}$, and $10 \mathrm{mg} / \mathrm{mL}$ ), control, and solvent (ethanol), in coprocultures positive for A. caninum eggs.

Results: In assay A, the results demonstrated inhibitory embryogenesis activity on T. canis eggs; however, no difference $(\mathrm{P}>0.01)$ was found between the activities of the extracts. In the control group, there was a difference $(\mathrm{P}<0.01)$ in relation to the tested extracts, in which this difference was not concentration-dependent. In assay B, all extracts showed inhibitory ( $P>0.01)$ hatchability activity of A. caninum eggs in the control group.

Conclusions: Through these results, the applicability of the used extracts in the control of eggs and/or larvae of T. canis and A. caninum is suggested. However, it is worth mentioning that further studies should be performed with the species E. edulis, M. glomerata and $M$. laevigata, using different extracts, new concentrations, and in vivo studies, in order to ensure further clarification on the agents responsible for the observed effects, degree of efficacy, and toxicity.
\end{abstract}

Keywords: Nematodes; Ancylostoma; Toxocara canis

\section{Background}

Gastrointestinal parasitoses have high rates of morbidity and mortality. Each year about 3.5 billion people are affected by these diseases and 65,000 of them die, mostly in developing countries due to lack of basic sanitation, malnutrition, and poor access to medication $(1,2)$. Thus, they constitute an important public health problem due to causing direct health problems related to lack of piped water, absence of sewage system, and lack of orientation $(3,4)$. Although there are several control strategies available to combat gastrointestinal nematodes that affect humans and animals, synthetic drugs are the most used, having great positive impact on the conservation of human and animal health (5). However, these drugs are not free of problems, such as drug resistance, and the amount of residual chemicals in the environment $(5,6)$. Therefore, the study for new control alternatives against these gastrointestinal parasites becomes imminent. Furthermore, the use of herbal extracts has shown great potential (7).

In this regard, various studies employing medicinal plants and their derivatives have shown ovicidal and larvicidal activities against several parasites (8-12). An in vitro study, conducted by Macedo et al. (8) with the essential oil of Eucalyptus globulus L. on hatching and development of Haemonchus contortus larvae, a gastrointestinal

Copyright (C) 2015, Infectious Diseases and Tropical Medicine Research Center. This is an open-access article distributed under the terms of the Creative Commons Attribution-NonCommercial 4.0 International License (http://creativecommons.org/licenses/by-nc/4.0/) which permits copy and redistribute the material just in noncommercial usages, provided the original work is properly cited. 
nematode of ruminants, showed ovicidal and/or larvicidal activity and potential for use in its control. In another study, methanol extracts obtained from Euphorbia helioscopia, showed anthelmintic activity when tested in vitro and in vivo on $H$. contortus, suggesting a treatment alternative in cases of infections due to helminths in ruminants (9).

Sensitivity of the gastrointestinal parasites Toxocara canis, and Ancylostoma caninum to other plant species was also observed. A study involving Carica papaya L. extract, suggested a potential role for this plant as an anthelmintic against infections caused by A. caninum in mice $(10,11)$. Another, in vitro study showed larvicidal activity of leaf extracts from $C$. ambrosioides L., against $T$. canis infective larvae (13).

\section{Objectives}

Thus, the aim of this study was to evaluate the ovicidal and/or larvicidal activity of the plants Euterpe edulis Martius, Mikania glomerata Spreng, and Mikania laevigata Schultz Bip. on the gastrointestinal nematodes T. canis and A. caninum, and investigate the larvicidal and/or ovicidal activity shown by these medicinal plants.

\section{Materials and Methods}

\subsection{Ethical Aspects}

The project was approved by the Ethics Committee on Animal Use (CEUA- UVV) of the University Vila Velha, Brazil (UVV-CEUA), according to the opinion consubstantiated No. 292/2013.

\subsection{Obtaining Plant Material and Preparation of Mikania glomerata Spreng and Mikania laevigata Schultz Bip. ex Baker Extracts}

The plants Mikania glomerata Spreng. and Mikania laevigata Schultz Bip. ex Baker were provided by the Sector of Medicinal Plants - Department of Agriculture, from the Federal University of Lavras (DAG/UFLA). Exsiccates from M. glomerata Spreng., and Mikania laevigata Schultz Bip. ex Baker were deposited in the herbarium of the Institute of Biosciences, UFRGS (Universidade Federal do Rio Grande do Sul), under the registration ICN141992 and ICN 141990.

The dried plant material from M. glomerata (260 g) and M. laevigata (100 g) was subjected to percolation with ethanol at $96^{\circ} \mathrm{GL}$. The ethanolic extract was concentrated in a rotary evaporator at $50^{\circ} \mathrm{C}$ under reduced pressure, until residue was obtained.

\subsection{Euterpe edulis Martius}

The fruits of palmito jucara ( $1 \mathrm{~kg}$ ) were provided by INCAPER (Espirito Santo Research Institute, Technical Assistance and Rural Extension), which is in accordance with the Normative Instruction 003/2013 (Espirito Santo, 2013). The sample was kept in a transparent plastic bag, with a hermetic closure, and kept in a domestic freezer at $-18^{\circ} \mathrm{C}$ until use.

The fibrous layer of the fruit, as well as the thin oily coverage, and the mesocarp were removed, and the ethanol extract of E. edulis was prepared using homogenization for 30 seconds, and $10 \mathrm{~g}$ of this material without the seed in $70 \mathrm{~mL}$ of aqueous ethanol $80 \%$. The mixture was subjected to an ultrasonic bath for 20 minutes.

\subsection{Obtaining Toxocara canis Eggs}

Pregnant, T. canis, adult females were dissected and uterine fragments containing eggs were removed. Subsequently, the eggs were centrifuged in distilled water. The content in the centrifuge tube was homogenized, and from it, three aliquots of $10 \mu \mathrm{L}$ were removed. Eggs were counted using a stereomicroscope at $\times 10$ magnification. The total amount of these eggs was estimated according to Araujo et al.(14).

\subsection{Obtaining Ancylostoma caninum Larvae}

About $150 \mathrm{~g}$ of fresh feces from dogs naturally infected with A. caninum were collected and used in the preparation of coprocultures. To do so, confirmation of contamination by A. caninum was required by means of a fecal flotation technique, in accordance with the technique of Willis-Mollay (15), and observation under an optical microscope, initially under a $\times 10$ objective, and later confirmed under a 40x objective. The average egg count per gram of feces (EPG) was 125 eggs/3g.

\subsection{Experimental Assays}

Two in vitro experimental assays, denominated $\mathrm{A}$ and $\mathrm{B}$, were performed. In assay $\mathrm{A}$, the percentage of embryonated T. canis eggs when using extracts from E. edulis, $M$. glomerata, and M. laevigata at different concentrations was evaluated, as described by Reis et al. (13). In assay B, the larvicidal activity of the species in different concentrations within coprocultures containing Ancylostoma caninum was evaluated.

\subsubsection{Assay A}

In this assay, 100 T. canis eggs were transferred into test tubes containing $5 \mathrm{~mL}$ of ethanolic extracts at concentrations $0.1 \mathrm{mg} / \mathrm{mL}, 1 \mathrm{mg} / \mathrm{mL}$, and $10 \mathrm{mg} / \mathrm{mL}$ of the medicinal plants in study (E. edulis, M. glomerata, and M. laevigata). The control group contained 100 eggs in $5 \mathrm{~mL}$ of ethanol (the same diluent used for preparation of the extracts) in the same container. A positive control was also performed using 100 eggs in test tubes containing albendazole at $0.01 \mathrm{mg} / \mathrm{mL}, 0.05 \mathrm{mg} / \mathrm{mL}$, and $0.1 \mathrm{mg} / \mathrm{mL}$ (13). There was also one group containing 100 eggs, which received no treatment. All tubes were properly identified and enclosed, and incubated at $26^{\circ} \mathrm{C}$, in the dark, for 15 days. 
Each treatment consisted of six replicates. After each study period, the total number of embryonated and/or non-embryonated eggs, present in each tube of the treated and control groups, was calculated according to the methodology described by Braga et al. (16).

\subsubsection{Statistical Analysis}

The average number of recovered fertilized eggs was calculated. Data were statistically interpreted by analysis of variance at significance levels of 1 and 5\% probability (17). The efficiency of embryonation compared to the control was assessed by Tukey's test at 1\% probability using the 5.0 BioEstat program. Subsequently, the average percentage reduction of embryonated eggs was calculated according to the following Equation 1:

Average presentage reduction of embryonated eggs $=$

(1) $\bar{x}_{\text {embryonated eggs from control }}{ }^{-}{ }^{-}$embryonated eggs from treatment $\bar{x}_{\text {embryonated eggs from control }} \times 100$

\subsubsection{Assay $B$}

Approximately, $3 \mathrm{~g}$ of positive feces were mixed with fragmented (autoclaved) industrial vermiculite and moistened in each cup. Subsequently, $10 \mathrm{~mL}$ of ethanolic extracts from E. edulis, M. glomerata, and M. laevigata were added at concentrations of $0.1 \mathrm{mg} / \mathrm{mL}, 1 \mathrm{mg} / \mathrm{mL}$, and $10 \mathrm{mg} / \mathrm{mL}$ and taken to BOD for 8 days at $26^{\circ} \mathrm{C}$, forming the treated group. Each treatment consisted of three replicates. Two control groups were performed: one consisting of the coprocultures without extracts and another containing only the solvent used (ethanol). At the end of this period, third stage larvae $\left(\mathrm{L}_{3}\right)$ were obtained by the Baermann method. These larvae were identified and quantified according to the criteria described by Urquhart et al. (18), in optical microscope and $10 \times$ objective.

\subsubsection{Statistical Analysis}

The average number of recovered $A$. caninum $\mathrm{L}_{3}$ was calculated. Data were statistically interpreted by analysis of variance at significance levels of 1 and 5\% probability (17). Destruction efficiency of $\mathrm{L}_{3}$ in relation to the control was assessed by Tukey's test at $1 \%$ probability, using the 5.0 BioEstat program. Subsequently the average percentage reduction of $\mathrm{L}_{3}$ was calculated according to the following Equation 2:

\section{Average presentage reduction of $\mathrm{L}_{3}=$}

$$
\text { (2) } \frac{{ }^{\bar{x}} \text { Recovered } L_{3} \text { from control }{ }^{-\bar{x}} \text { Recovered } L_{3} \text { from treatment }}{{ }^{-} \text {Recovered } L_{3} \text { from control } \times 100}
$$

\section{Results}

\subsection{Assay A}

The embryogenesis of $T$. canis eggs occurred properly during assay A, as shown in the control, and the results obtained after 15 days of interaction between eggs and ethanol extracts are shown in Table 1 . All investigated species (M. glomerata, M. laevigata, and E. edulis) showed inhibitory activity in the percentage of embryonated T. canis eggs in relation to the control group. Table 2 shows the results of the positive control (Albendazole), and the negative control with the solvent used in the extracts (ethanol), under the same analysis conditions of the assay A.

Table 1. Averages and Standard Deviations of the Percentage of Embryonated Toxocara canis Eggs After Prior Contact With the Groups Treated With Ethanol Extracts From Mikania laevigata, Mikania glomerata, Euterpe edulis, and the Control Group After 15

\begin{tabular}{|c|c|c|}
\hline $\begin{array}{l}\text { Species Extract } \\
\text { Concentration }\end{array}$ & Average, $\%^{\mathrm{a}}$ & Embryonation, \% \\
\hline \multicolumn{3}{|c|}{ Mikania laevigata } \\
\hline $0.1, \mathrm{mg} / \mathrm{mL}$ & $43.3 \pm 22.5$ & 56.7 \\
\hline $1, \mathrm{mg} / \mathrm{mL}$ & $59.1 \pm 11.1$ & 40.9 \\
\hline $10, \mathrm{mg} / \mathrm{mL}$ & $31.6 \pm 15.7$ & 68.4 \\
\hline Control & 100 & 100 \\
\hline \multicolumn{3}{|c|}{ Mikania glomerata } \\
\hline $0.1, \mathrm{mg} / \mathrm{mL}$ & $40.8 \pm 22.5$ & 59.2 \\
\hline $1, \mathrm{mg} / \mathrm{mL}$ & $42.5 \pm 11.1$ & 57.5 \\
\hline $10, \mathrm{mg} / \mathrm{mL}$ & $31.6 \pm 15.7$ & 68.4 \\
\hline Control & 100 & 100 \\
\hline \multicolumn{3}{|l|}{ Euterpe edulis } \\
\hline $0.1, \mathrm{mg} / \mathrm{mL}$ & $57 \pm 22.5$ & 43 \\
\hline $1, \mathrm{mg} / \mathrm{mL}$ & $40.8 \pm 11.1$ & 59.2 \\
\hline $10, \mathrm{mg} / \mathrm{mL}$ & $35 \pm 15.7$ & 65 \\
\hline Control & 100 & 100 \\
\hline
\end{tabular}
Days of Interaction

Table 2. Averages and Standard Deviations of the Percentages of Embryonated Toxocara canis Eggs After Previous Contact With the Groups Treated With Albendazole and Ethanol After 15 Days of Interaction.

\begin{tabular}{lcc}
\hline Treatment & Average, ${ }^{\mathrm{a}}$ & Embryonation, $\%$ \\
\hline Albendazol, $\mathbf{~ m g} / \mathbf{m L}$ & & \\
0.01 & $43.3 \pm 22.5$ & 56.7 \\
0.05 & $59.1 \pm 10.8$ & 40.9 \\
0.1 & $68.3 \pm 15.7$ & 31.7 \\
Etanol & $31.6 \pm 11.7$ & 68.4 \\
Control & 100 & 100 \\
\hline a Different values in this column do not differ, $\mathrm{P}>0.05$ and $\mathrm{P}>0.01$ - \\
Tukey.
\end{tabular}




\subsection{Assay B}

In assay B, as shown in Table 3, all ethanol extracts tested (M. glomerata, M. laevigata, and E. edulis) in coprocultures were able to inhibit the hatching of A. caninum eggs after 8 days of interaction; although no significant difference $(\mathrm{P}>0.01)$ was observed compared to the exposure concentration of the extract, showing only difference compared to the control.

Table 3. Averages and Standard Deviations of the Percentages of Ancylostoma caninum Infective Larvae $\left(\mathrm{L}_{3}\right)$ Recovered from Coprocultures in the Groups Treated With Ethanol Extracts From Mikania laevigata, Mikania glomerata, Euterpe edulis and the Control Group After 8 Days of Interaction

\begin{tabular}{|ccc}
\hline $\begin{array}{l}\text { Species Extract } \\
\text { Concentration }\end{array}$ & Average, ${ }^{\mathrm{a}}$ & Embryonation, \% \\
\hline Mikania laevigata & & \\
\hline $0.1, \mathrm{mg} / \mathrm{mL}$ & $4.9 \pm 2.9$ & 57.3 \\
$1, \mathrm{mg} / \mathrm{mL}$ & $3.0 \pm 1.7$ & 73.9 \\
\hline $10, \mathrm{mg} / \mathrm{mL}$ & $2.7 \pm 2.7$ & 78.2 \\
\hline Control & $11.5 \pm 3.1$ & 0 \\
\hline Mikania glomerata & & \\
\hline $0.1, \mathrm{mg} / \mathrm{mL}$ & $4.5 \pm 3.5$ & 56.9 \\
\hline $1, \mathrm{mg} / \mathrm{mL}$ & $3.1 \pm 4.7$ & 69.5 \\
\hline $10, \mathrm{mg} / \mathrm{mL}$ & $2.7 \pm 2.0$ & 74.1 \\
\hline Control & $10.4 \pm 4.3$ & 0 \\
\hline Euterpe edulis & & \\
\hline $0.1, \mathrm{mg} / \mathrm{mL}$ & $2.4 \pm 1.4$ & 74.7 \\
\hline $1, \mathrm{mg} / \mathrm{mL}$ & $5.75 \pm 5.2$ & 39.4 \\
\hline $10, \mathrm{mg} / \mathrm{mL}$ & $2.0 \pm 1.7$ & 78.9 \\
\hline Control & $9.5 \pm 4.7$ & 0 \\
\hline
\end{tabular}

$\mathrm{a}$ Different values in this column do not differ, $\mathrm{P}>0.05$ and $\mathrm{P}>0.01$ Tukey.

\section{Discussion}

There are few studies that assess, or demonstrate, plant in vitro antiparasitic activity on $T$. canis eggs. Most research is directed towards the evaluation of T. canis larvae $(13,19)$ or towards the activity of nematophagous fungi, among which Pochonia chlamydosporia, which mostly produce proteases capable of destroying the eggs of gastrointestinal nematodes (16).

Regarding the ethanol extracts tested, there is no significant difference between the concentrations investigated $(0.1 \mathrm{mg} / \mathrm{mL}, 1 \mathrm{mg} / \mathrm{mL}$, and $10 \mathrm{mg} / \mathrm{mL})$, unlike that found by Lone et al. (9) in their in vitro study with extracts from Euphorbia heliscopia on H. contortus, were the extract concentration was more effective in inhibiting parasite motility as it was increased, $12.5,25$, and $50 \mathrm{mg} / \mathrm{mL}$.

In general, a plant extract contains low concentrations of active compounds, but in large numbers (20). Thus, the use of in vitro assays with medicinal plant extracts, in addition to the benefits of ease of use, low cost, and speed, serve as an early indication of the activity being investigated and allow the selection of the most promising extracts, decrease spending, avoid loss of time and the indiscriminate use of laboratory animals (21).

According to Gasparetto et al. (22) diterpenes, especially the class of kauranes, present in the species M. glomerata and $M$. laevigata, antiparasitic activity among other pharmacological actions, corroborating with the results found here, in which extracts from M. laevigata and $M$. glomerata showed embryonation rates lower than the control, i.e. there were substances capable of preventing embryogenesis of $T$. canis eggs in these extracts. Vieira et al. (23) also endorse this information when reporting the antiparasitic activity of a cauranic diterpene, on trypomastigote forms of Trypanosoma cruzi, in an in vitro study. The species E. edulis has not yet been explored regarding its antiparasitic activity; however, studies have demonstrated the antiparasitic activity of flavonoids, substance found in E. edulis. Quercetin, a flavonoid revealed in an in vitro study by Weiss et al. (24), was able to inhibit the synthesis of hsp90, hsp70, hsp27, and even suppress the induction and development of bradyzoite in Toxoplasma gondii. Tasdemir et al. (25) have also demonstrated that quercetin and their derivatives exhibit promising in vitro activities against the generas Leishmania and Trypanosoma. Molan et al. (26) demonstrated the in vitro anthelmintic activity of various flavonoids and their derivatives, including epicatechin and catechin, also present in E. edulis, on T. colubriformis eggs and larvae, nematode affecting ruminants, in a concentrationdependent relation; contradicting the findings in this assay with E. edulis, where the percentage difference $(\mathrm{P}>$ 0.01) of embryonated T. canis eggs although higher when compared to control, did not increase depending on the concentration.

According to the data obtained by statistical analysis, assay B, obtained satisfactory results in all tested ethanol extracts and their concentrations from M. laevigata, M. glomerata, and E. edulis $(0.1 \mathrm{mg} / \mathrm{mL}, 1 \mathrm{mg} / \mathrm{mL}$, and 10 $\mathrm{mg} / \mathrm{mL}$ ), since the A. caninum eggs hatched resulting in a considerable number when compared with the control group, which did not contain any concentration of the extract. It's worth mentioning that a solvent control (ethanol) was also conducted and it also did not interfere with the assay's results.

In a study conducted by Assis et al. (27) H. contortus larvae and eggs were subjected to four different extracts: hexane, chloroform, ethyl acetate, and methanol at five different concentrations (3.1, 6.2, 12.5, 25.0, and $50.0 \mathrm{mg} /$ $\mathrm{mL}$ ) obtained from the plant Spigelia anthelmia. At the concentration of $50.0 \mathrm{mg} / \mathrm{mL}$, the ethyl acetate extract inhibited $100 \%$ of egg hatching, and $81.2 \%$ of larval development. Similarly, the methanol extract inhibited $97.4 \%$ of hatching and $84.4 \%$ of $H$. contortus larvae in development, while the other extracts showed lower or statistically 
igual percentages to the control, such as the chloroform extract at a concentration of $50.0 \mathrm{mg} / \mathrm{mL}$.

The results showed that the ethanol extracts from $M$. laevigata, M. glomerata, and E. edulis in the tested concentrations $(0,1 \mathrm{mg} / \mathrm{mL}, 1 \mathrm{mg} / \mathrm{mL}$, and $10 \mathrm{mg} / \mathrm{mL})$, showed ovicidal and/or larvicide activity on the gastrointestinal nematodes T. canis and A. caninum. There was no difference between extracts from M. laevigata, M. glomerata and E. edulis in relation to ovicidal and/or larvicide activity on the gastrointestinal nematodes investigated $(\mathrm{P}>0.01)$. Tested concentrations of these extracts $(0.1 \mathrm{mg} / \mathrm{mL}, 1 \mathrm{mg} /$ $\mathrm{mL}$, and $10 \mathrm{mg} / \mathrm{mL})$ did not differ $(\mathrm{P}>0.01)$ from each other, regarding the ovicidal and/or larvicidal activity on T. canis and A. caninum. However, further in vivo studies are needed for the improvement of the methodology and for further clarification of the agents responsible for the observed effects, action mechanisms.

\section{Acknowledgements}

The authors would like to thank Fapes, CNPq, and Fapemig for their financial support and grant concession.

\section{References}

1. Fauci AS. Infectious diseases: considerations for the 21st century. Clin Infect Dis. 2001;32(5):675-85.

2. Brooker S. Estimating the global distribution and disease burden of intestinal nematode infections: adding up the numbers-a review. Int J Parasitol. 2010;40(10):1137-44.

3. Fonseca EO, Teixeira MG, Barreto ML, Carmo EH, Costa Mda C. [Prevalence and factors associated with geohelminth infections in children living in municipalities with low HDI in North and Northeast Brazil]. Cad Saude Publica. 2010;26(1):143-52.

4. Vasconcelos IAB, Oliveira JW, Cabral FRF, Coutinho HDM, Menezes IRA. Prevalence of intestinal parasite infections among 4- to 12-year-old children in Crato, Ceará State [in Portuguese]. Acta Sci Health Sci. 2011;33(1):35-41.

5. Stepek G, Behnke JM, Buttle DJ, Duce IR. Natural plant cysteine proteinases as anthelmintics? Trends Parasitol. 2004;20(7):322-7.

6. Dalton JP, Mulcahy G. Parasite vaccines-a reality? Vet Parasitol. 2001;98(1-3):149-67.

7. Tagboto S, Townson S. Antiparasitic properties of medicinal plants and other naturally occurring products. Adv Parasitol. 2001;50:199-295.

8. Macedo IT, Bevilaqua CM, de Oliveira LM, Camurca-Vasconcelos AL, Vieira Lda S, Oliveira FR, et al. [Ovicidal and larvicidal activity in vitro of Eucalyptus globulus essential oils on Haemonchus contortus]. Rev Bras Parasitol Vet. 2009;18(3):62-6.

9. Lone BA, Chishti MZ, Bhat FA, Tak H, Bandh SA. In vitro and in vivo anthelmintic activity of Euphorbia helioscopia L. Vet Parasitol. 2012;189(2-4):317-21.

10. Bi S, Goyal PK. Anthelmintic effect of Natural Plant (Carica papa- ya) extract against the Gastrointestinal nematode Ancylostoma caninum in Mice. ISCA J Biological Sci. 2012;1:2-6.

11. Sousa RG, Falcao HS, Barbosa Filho JM, Melo Diniz MFF, Batista LM. Atividade anti-helmíntica de plantas nativas do continente americano: uma revisão. Revista Brasileira de Plantas Medicinais. 2013;15(2):287-92.

12. Sa-Nunes A, Rogerio AP, Medeiros AI, Fabris VE, Andreu GP, Rivera DG, et al. Modulation of eosinophil generation and migration by Mangifera indica L. extract (Vimang). Int Immunopharmacol. 2006;6(9):1515-23.

13. Reis M, Trinca A, Ferreira MJ, Monsalve-Puello AR, Gracio MA. Toxocara canis: potential activity of natural products against secondstage larvae in vitro and in vivo. Exp Parasitol. 2010;126(2):191-7.

14. Araujo JV, Santos MA, Ferraz S. Efeito ovicida de fungos nematófagos sobre ovos embrionados de Toxocara canis. Braz Arch Vet Med Anim Sci.1995;47(1):37-42.

15. Araujo JV. Diagnosis of helminths: didactic notebook.Vicosa: UFV; 2006.

16. Braga FR, Araujo JM, Silva AR, Araujo JV, Carvalho RO, Soares FE, et al. [Ovicidal action of a crude enzymatic extract of fungus Pochonia chlamydosporia against Ancylostoma sp eggs]. Rev Soc Bras Med Trop. 2011;44(1):116-8.

17. Ayres M, Ayres JM, Ayres DL, Santos AS. Statistical applications in the areas of biomedical sciences.Belem; 2003.

18. Urquhart GM, Armour J, Duncan JL, Dunn AM, Jennings FW. Veterinary Parasitology.Rio de Janeiro: Guanabara Koogan.

19. Satou T, Horiuchi A, Akao N, Koike K, Fujita K, Nikaido T. Toxocara canis: search for a potential drug amongst beta-carboline alkaloids--in vitro and mouse studies. Exp Parasitol. 2005;110(2):134-9.

20. Rates SM. Plants as source of drugs. Toxicon. 2001;39(5):603-13.

21. Camurca-Vasconcelos AL, Bevilaqua CM, Morais SM, Maciel MV Costa CT, Macedo IT, et al. Anthelmintic activity of Croton zehntneri and Lippia sidoides essential oils. Vet Parasitol. 2007;148(34):288-94.

22. Gasparetto JC, Campos FR, Budel JM, Pontarolo R. Mikania glomerata Spreng. e M. laevigata Sch. Bip. ex Baker, Asteraceae: agronomic, genetic, anatomical, chemical, pharmacological, toxicological studies and its use in herbal therapy programs in Brazil. Braz J Pharmacogn . 2010;20(4):627-40.

23. Vieira SH, Takahashi J. A. , Oliveira AB, Chiari E, Boaventura MA. Novel Derivatives of Kaurenoic Acid. J Braz Chem Soc. 2002;13(2):151-7.

24. Weiss LM, Ma YF, Takvorian PM, Tanowitz HB, Wittner M. Bradyzoite development in Toxoplasma gondii and the hsp70 stress response. Infect Immun. 1998;66(7):3295-302.

25. Tasdemir D, Kaiser M, Brun R, Yardley V, Schmidt TJ, Tosun F, et al Antitrypanosomal and antileishmanial activities of flavonoids and their analogues: in vitro, in vivo, structure-activity relationship, and quantitative structure-activity relationship studies. Antimicrob Agents Chemother. 2006;50(4):1352-64.

26. Molan AL, Meagher LP, Spencer PA, Sivakumaran S. Effect of flavan-3-ols on in vitro egg hatching, larval development and viability of infective larvae of Trichostrongylus colubriformis. Int $J$ Parasitol. 2003;33(14):1691-8.

27. Assis LM, Bevilaqua CM, Morais SM, Vieira LS, Costa CT, Souza JA. Ovicidal and larvicidal activity in vitro of Spigelia anthelmia Linn. extracts on Haemonchus contortus. Vet Parasitol. 2003;117(1-2):43-9. 